\title{
ROOT CARBOHYDRATE STORAGE IN YOUNG SAPLINGS OF AN AMAZONIAN TIDAL VÁRZEA FOREST BEFORE THE ONSET OF THE WET SEASON ${ }^{1,2}$
}

\author{
Fabio Rubio Scarano ${ }^{3}$ \\ José Henrique Cattânio ${ }^{4}$ \\ Robert M.M. Crawford ${ }^{5}$
}

Recebido em 26.03.93. Aceito em 30.06.94

\begin{abstract}
RESUMO - (Armazenamento de carboidratos antecedendo à estação chuvosa em raízes de plantas jovens em floresta de várzea de estuário amazônico). Conteúdo de amido e glucose foi medido em raízes de plantas jovens de 18 espécies arbóreas de várzea de estuário amazônico durante o pico da estação seca, antecedendo o início da estação chuvosa. O padrão de armazenamento de carboidratos dependeu do tipo de planta envolvido e da topografia do terreno, que é diretamente ligada ao regime de inundação. Parte das espécies estudadas mostrou alto conteúdo de carboidratos neste período, contudo, várias espécies tipicamente tolerantes à inundação (particularmente palmeiras) mostraram baixa concentração de carboidratos neste ponto antecedendo a estação chuvosa. Tal resposta sugere a existência para estas espécies de uma estratégia de aquisição de reservas durante a estação de cheia para uso durante a estação seca. Sobrevivência vegetal nestas florestas inundáveis parece resultar de mais de um único mecanismo adaptativo.
\end{abstract}

Palavras-chave: Amazônia, carboidratos, inundação, raízes, várzea de estuario.

ABSTRACT - (Root carbohydrate storage in young saplings of an Amazonian tidal "várzea" forest before the onset of the wet season). Root starch and glucose content were measured for young saplings of 18 Amazonian tidal várzea tree species during a dry season. The pattern of carbohydrate storage depended on the type of plant involved and soil topography which is directly linked to flood regime. Most plants showed high root carbohydrate content at this point in the dry season, however, several typically flood-tolerant species (particularly palm trees) presented a low root carbohydrate content, suggesting a strategy of acquiring reserves during the wet season to survive the dry season, when depletion occurs. Plant survival in these flood-prone forests seems to be the result of more than only one adaptive mechanism.

Key words: Amazon, carbohydrate, flooding, roots, tidal várzea.

\footnotetext{
'Sponsored by ODA-British Council and developed at the Combu Project, Belém, and St. Andrews University, Scotland.

2 Paper given at the XLIV Congresso Nacional de Botânica, São Luís- Maranhão, Brasil.

${ }^{3}$ Departamento de Ecologia. Universidade Federal do Rio de Janeiro. Cidade Universitária, CCS - Bloco A. CEP 21941-970. Rio de Janeiro-RJ, Brasil.

${ }^{4}$ Depto. de Ecologia. Museu Paraense Emílio Goeldi. Caixa Postal 399. CEP 66040. Belém-PA, Brasil.

s School of Life Sciences, Sir Harold Mitchell Building, The University, St.Andrews, KY16 9AJ, Scotland.
} 


\section{Introduction}

Flooding is a recurring phenomenon in many areas of the Amazon forest varying in nature, duration and depth. This has been described as one of the reasons that led to the present existence of a mosaic of habitats in the Amazonian floodplains (Junk, 1989). These distinct habitats were classified by Prance (1979) into seven groups. The habitat examined in the present work is what Prance called a tidal swamp forest, from the portuguese mata de várzea de estuário, which here will be called tidal várzea. These forests are often submitted twice daily to fresh water flooding backed up from tides. High tides temporarily block the flow of the rivers in the estuarine region and cause them to flood the adjacent forest.

Despite the economic relevance of the tidal várzea forests (rich in palm trees, wood, and possessing a soil richer than most in the Amazon), few studies have attempted to investigate the effects of flooding on the plant species of these areas. Unfortunately, the shortage of ecophysiological information is also true for the rest of the Amazonian floodplains. Scarano and Crawford (1992) using Parkia pendula and Parkia discolor discussed flooding phenology and the concept of flood-tolerance. Junk (1989) related tree distribution with flood-tolerance for the Central Amazonian floodplains. Worbes (1985) studying the structural adaptations of trees to flooding in the Central Amazon, suggested that the adaptability of trees to flooding in the várzea forests is bound to be physiological rather than due to anatomical properties.

The ability to store carbohydrates in underground organs before the rainy season is one of the strategies that often guarantees survival for the plant during flooding (Steinmann \& Brändle, 1984; Crawford, 1992), since anaerobic metabolism is costly in terms of carbohydrate consumption as compared with normal aerobic respiration (Crawford et al. 1989). There are few works which refer to carbohydrate balance in tropical plants. In an early review by Kozlowski \& Keller (1966) reference is made to some tropical studies. Figueiredo-Ribeiro et al. (1986) studied reserve carbohydrates in the underground organs of Brazilian savanna (cerrado) plants. The present work uses the acquisition of carbohydrate before a potentially adverse flooding season as an initial parameter in comparing flood-tolerance in young saplings of various species of a tidal várzea forest in eastern Amazon.

\section{Material and methods}

Field work

The sampling of roots for carbohydrate analysis took place in Combu, a fluvial island of the river Guamá, near the city of Belém in the eastern part of the Brazilian Amazon. The area studied is a research work station of the Museu Paraense Emílio Goeldi. Root sampling was carried out on October 9th and 10th, 1991, at the characteristic peak of the dry season. At this time of the year flooding does not occur as often as during the rainy season (see Results). 
A selection of uniform young saplings (based on height and number of leaves) for a same species, present in areas of high or low topography, was carried out for 18 tree species before subsequent root harvest (Table 1). For taxonomic identification of the species studied, vegetative material of saplings was compared with that of identified adults. The main methodological difficulty encountered was to reach a uniformity of age for all eighteen species studied. It was possible, however, to estimate the age of the species studied as ranging from 1 to 3 years old. Species present in both high and low topography were sampled in both areas, producing a total of 24 samples. For each sample, five replicates of one plant each were collected. It is important to highlight that the so-called high topography area is only $56 \mathrm{~cm}$ higher than the low topography area, which is, however, enough of a difference to provoke changes in physiognomy and species composition of the two areas (see Results). Root sampling in most cases was done simply by carefully pulling the whole plant as an intact core out of the soil. When the soil presented resistance, plants were carefully dug out of the soil, making sure the roots were intact. After harvest, root and shoot length were measured, and the total number of leaves presented by each plant observed (data not shown). Subsequently the root system as a whole of each plant was deep frozen in liquid nitrogen, wrapped in alluminium foil and placed in incubators at below zero temperatures with silica gel. At the end of a day of collection the material would be transported to the laboratories of CPATU-EMBRAPA in Belém where freeze drying took place. A week later, the root material was transported to The University of St.Andrews, Scotland, where carbohydrate analysis was carried out.

\section{Carbohydrate analysis}

Enzymatic analysis was used to determine starch and D-glucose content in the samples. Roots were reduced to a fine powder, and $100 \mathrm{mg}$ of this was treated with 5.0 $\mathrm{ml}$ hydrochloric acid / $20.0 \mathrm{ml}$ dimethylsulphoxide to solubilize the starch and the Dglucose present. Subsequently the solutions were left for 30 minutes in a $60^{\circ} \mathrm{C}$ water bath, before being filtered through sterilized muslin. The $\mathrm{pH}$ of the extracts was adjusted to 4.5 and the total volume increased to $100 \mathrm{ml}$ by addition of distilled water. Boehringer-Mannheim kits for biochemical analysis of starch were used to perform the enzymatic analysis in a Pye Unicam ultra-violet spectrophotometer. Starch was hydrolised to D-glucose with the addition of amyloglucosidase. An enzyme suspension consisting of hexokinase and glucose-6-phosphate dehydrogenase was used in Dglucose and starch determination. The measurements were made at room temperature using glass cuvettes $(1 \mathrm{~cm}$ light path) and a $340 \mathrm{~nm}$ wavelength. Details of the methodology are described in the instruction leaflet which accompanies the kits (Boehringer \& Mannheim 1987). 
Table 1. List of species studied and topography of the site where they were selected for root harvest and subsequent carbohydrate analysis.

\begin{tabular}{cc}
\hline Species studied & high low \\
area & area \\
\hline
\end{tabular}

1) Palm species

Astrocaryum murumuru Mart.

Bactris sp.

Euterpe oleracea Mart.

Maximiliana maripa (Correa) Drude

Raphia taedigera Mart.

Socratea exhorriza (Mart.) Wendland

$\begin{array}{rr}X & X \\ - & X \\ X & X \\ X & - \\ - & X \\ X & -\end{array}$

2) Leguminosae

Inga edulis Mart.

Inga nobilis Willd.

Pentachlethra macroloba (Willd.) Ktze.

Pithecellobium cauliflorum (Willd.) Mart.

Pithecellobium latifolium (L.) Benth.

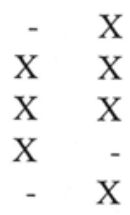

3) Other Dicotyledons

a. Bombacaceae

Matisia paraensis Huber $\quad$ - $\mathrm{X}$

b. Burseraceae

Pseudobombax munguba (Mart. et Zucc.) Robyns - $\quad$ - X

Protium sp.

c. Lecythidaceae

Eschweilera coriacea (D.C.) Mart. ex Berg

d. Meliaceae

Carapa guianensis Aubl

Guarea kunthiana Adr.Jussieu

e. Myristicaceae

Virola surinamensis (Rol.) Warb. - X

f. Sterculiaceae

Sterculia speciosa K.Schum.

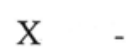

X -

$\mathrm{X} \quad \mathrm{X}$

X -

X

\section{Results}

The gradient of only $56 \mathrm{~cm}$ between high and low várzea is enough to establish a distinct flood regime for each area. During the wet season the main difference is in regard to duration of flooding: the high area is flooded twice daily and the low area is 
flooded permanently. For most of the dry season, the low areas are flooded once or twice daily and the high areas are flooded twice a month or less, depending on rainfall. At the time roots were harvested for the present work, the low areas were flooded once daily and the high areas had been already ca. 3 months free of flooding, possibly due to an uncommonly severe dry season in 1991. In this context, the results can be seen as reflecting the response of plants to dry soils (high area) and to soils alternately waterlogged (low areas).

The saplings presently studied showed differential response to soil water saturation and topography, in terms of carbohydrate storage. Dividing the species studied into three groups - i) palm trees; ii) leguminous trees; and iii) other tree species provided the pattern seen in Figure 1. Palm species in the low topography areas show only $20 \%$ of the root starch and $41 \%$ of the root glucose presented in the higher areas. Leguminous species showed similar amounts of both carbohydrates for high and low area. The other tree species, however, showed $35 \%$ more starch and $28 \%$ more glucose in the lower than in the higher areas.

Examination within each of these plant groups shows that more variation in the pattern of carbohydrate storage can be detected.

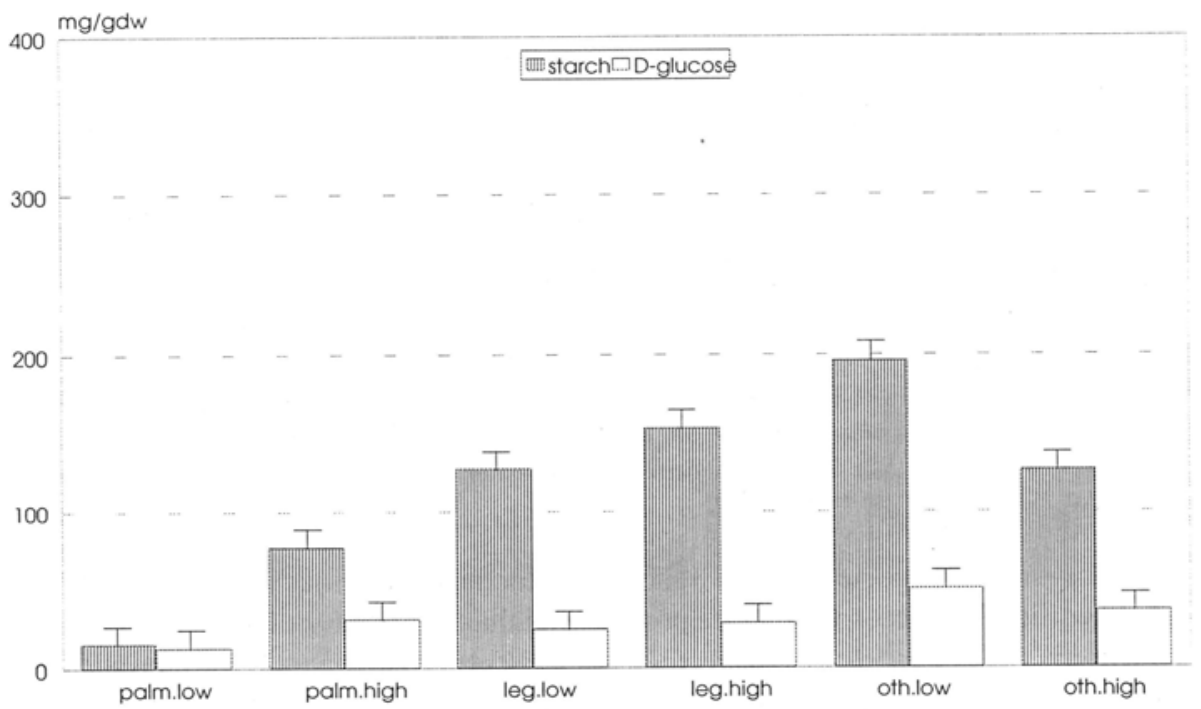

Figure 1. Mean starch and D-glucose concentration (mg.gdw $\mathrm{gdr}^{-1}$ ) of roots of saplings of palm species (palm), leguminous tree species $(\mathrm{leg})$ and other dicotyledonous tree species (oth), at two distinct topographical areas (high and low) in an Amazonian tidal várzea forest, before the onset of the wet season. Flooding is longer and more frequent for the lower areas. Bars indicate standard error. $\mathrm{n}=20$ for palms, leguminous trees and other dicots at the lower topography and for palms at the higher topography (4 species in each group, each with 5 plants sampled). $\mathrm{n}=15$ for leguminous trees at the higher topography ( 3 species, each with 5 plants sampled). $\mathrm{n}=25$ for other dicots at the higher topography ( 5 species, each with 5 plants sampled). 
Palm species - Euterpe oleracea and Astrocaryum murumuru are species of common occurrence in high and in low areas of the tidal várzea forests. Figure 2 shows that the carbohydrate stored in the roots of both species was reduced irrespective of topography, if compared with palms predominantly present in high areas (Maximiliana maripa and Socratea exhorriza). Reduced quantities were equally found in Raphia taedigera and Bactris sp, which are characteristic of low areas. Similarly, Maximiliana maripa and Socratea exhorriza presented considerably higher starch:glucose ratio than their low and high/low area counterparts.

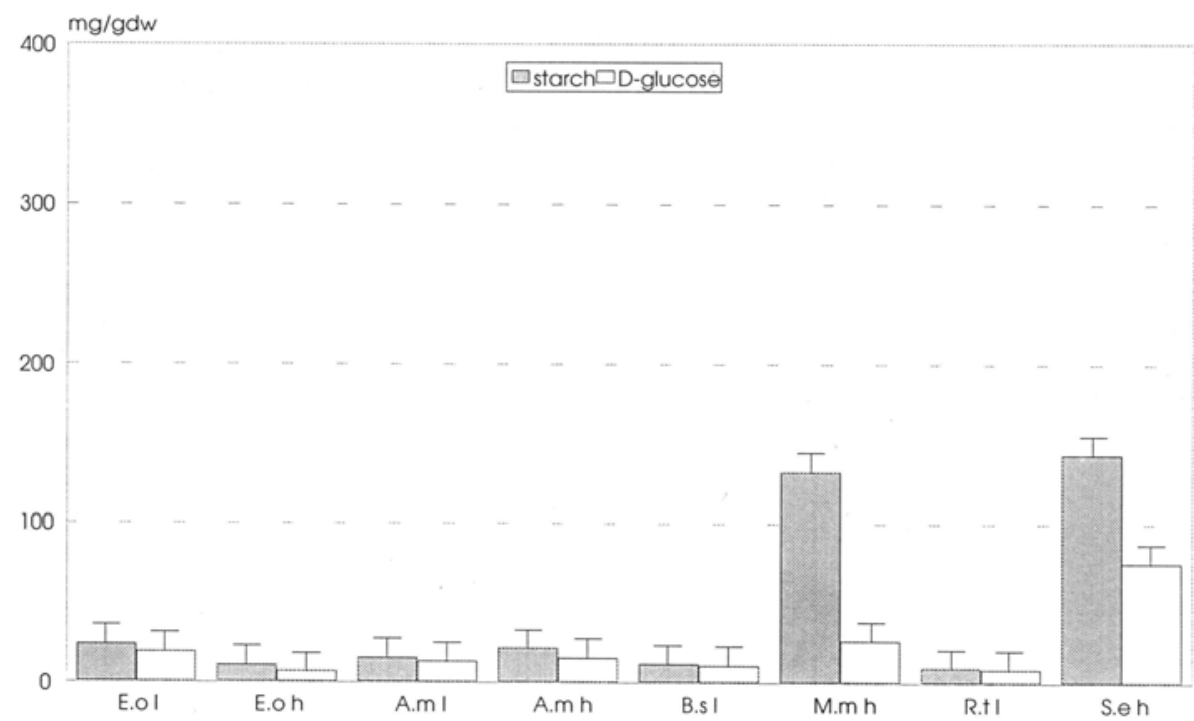

Figure 2. Mean starch and D-glucose concentration (mg.gdw ${ }^{-1}$ ) of saplings of six palm species present in areas of high $(h)$ and/or low $(l)$ topography in an Amazonian tidal várzea forest, before the onset of the wet season: Euterpe oleracea (E.o), Astrocaryum murumuru (A.m), Bactris sp (B.s), Maximiliana maripa $(M . m)$, Raphia taedigera (R.t), Socratea exhorriza (S.e). Flooding is longer and more frequent for the lower areas. Bars indicate standard error. $\mathrm{n}=5$.

Leguminous species - Figure 3 shows that for the leguminous species the intra and interspecific differences were more pronounced than in the case of the palm saplings. Inga nobilis and Pentaclethra macroloba are present in both topographies but showed, nevertheless, opposite patterns of storage. Inga nobilis presented $63 \%$ lower starch levels in the low area compared with the high area, whereas Pentaclethra macroloba showed $49 \%$ higher starch levels in the low area compared with the high areas. Another Inga species, Inga edulis, which is predominantly of low areas, had however $34 \%$ more starch than Inga nobilis of high area and $76 \%$ more than Inga nobilis of low area, probably characterising adaptation to flooding regimes. An opposite case of interspecific variation within the same genus is observed for Pithecellobium. Pithecellobium cauliflorum, characteristic of high areas showed $87 \%$ higher starch levels than 
Pithecellobium latifolium, its characteristically low area counterpart. Glucose was stored in similar amounts for all the leguminous species sampled. For this reason those species with higher starch levels showed higher starch:glucose ratio.

Other dicotyledonous species - In this group only Carapa guianensis (Meliaceae) is commonly present in both high and low areas. This species seems to use different strategies for each area: in the low topography it has twice the starch and half the glucose stored in high areas (Figure 4). The starch:glucose ratio is 2:1 in the high area and 8:1 in the low area. Figure 5 indicates that the predominantly low area species (Matisia paraensis, Virola surinamensis and Pseudobombax munguba) were generally richer in starch and glucose than the characteristically high area species (Guarea kunthiana, Sterculia speciosa, Protium sp. and Eschweilera coriacea). Pseudobombax munguba had the highest starch levels among the species studied (303.25 $\left.\mathrm{mg} . \mathrm{gdw}^{-1}\right)$. The starch:glucose ratio was often similar among the species in this group, with the exception of low area Virola surinamensis which ratio was high compared to the others $(15: 1)$.

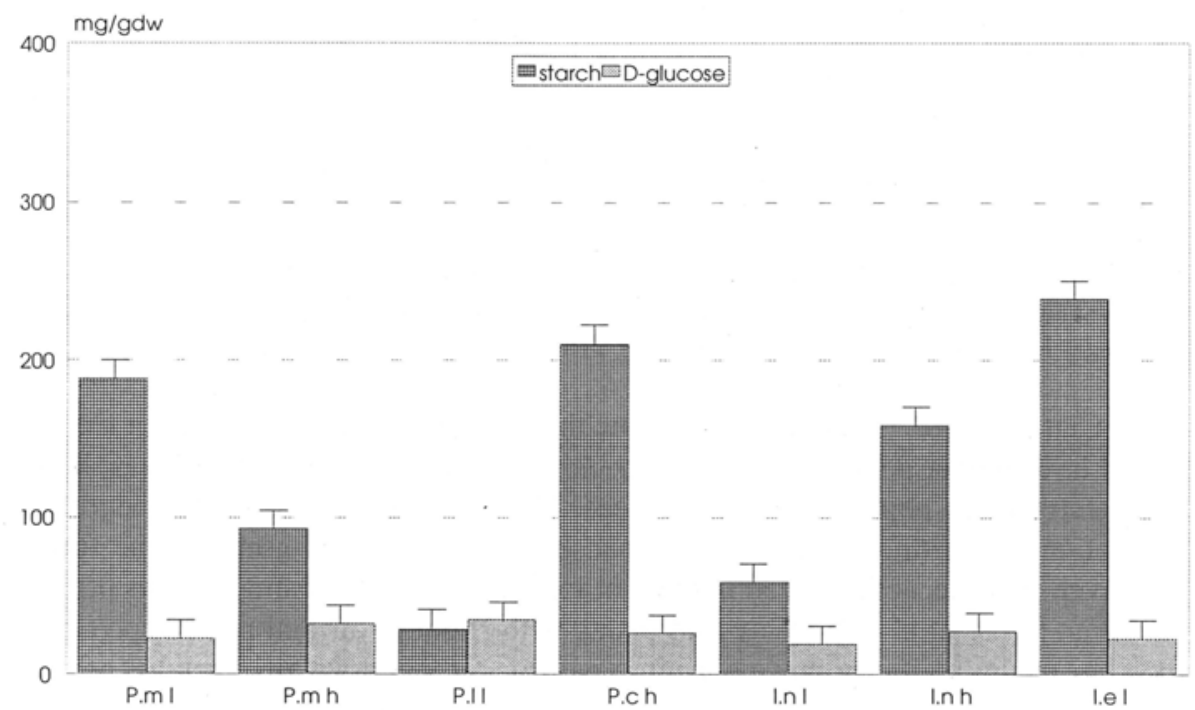

Figure 3. Mean starch and D-glucose concentration $\left(\mathrm{mg} . \mathrm{gdw}^{-1}\right)$ of saplings of five leguminous tree species present in areas of high $(h)$ and/or low $(l)$ topography in an Amazonian tidal várzea forest, before the onset of the wet season: Pentaclethra macroloba (P.m), Pithecellobium latifolium (P.l), Pithecellobium cauliflorum (P.c), Inga nobilis (I.n), Inga edulis (I.e). Flooding is longer and more frequent for the lower areas. Bars indicate standard error. $\mathrm{n}=5$.

Discussion

The root carbohydrate storage of the saplings studied varied according to soil water saturation, topography and type of plant involved. The different patterns of 
carbohydrate storage presented by different groups of plants may reflect the existence of distinct adaptive strategies of survival. These variations in response could also be observed within the groups, intra and interspecifically.

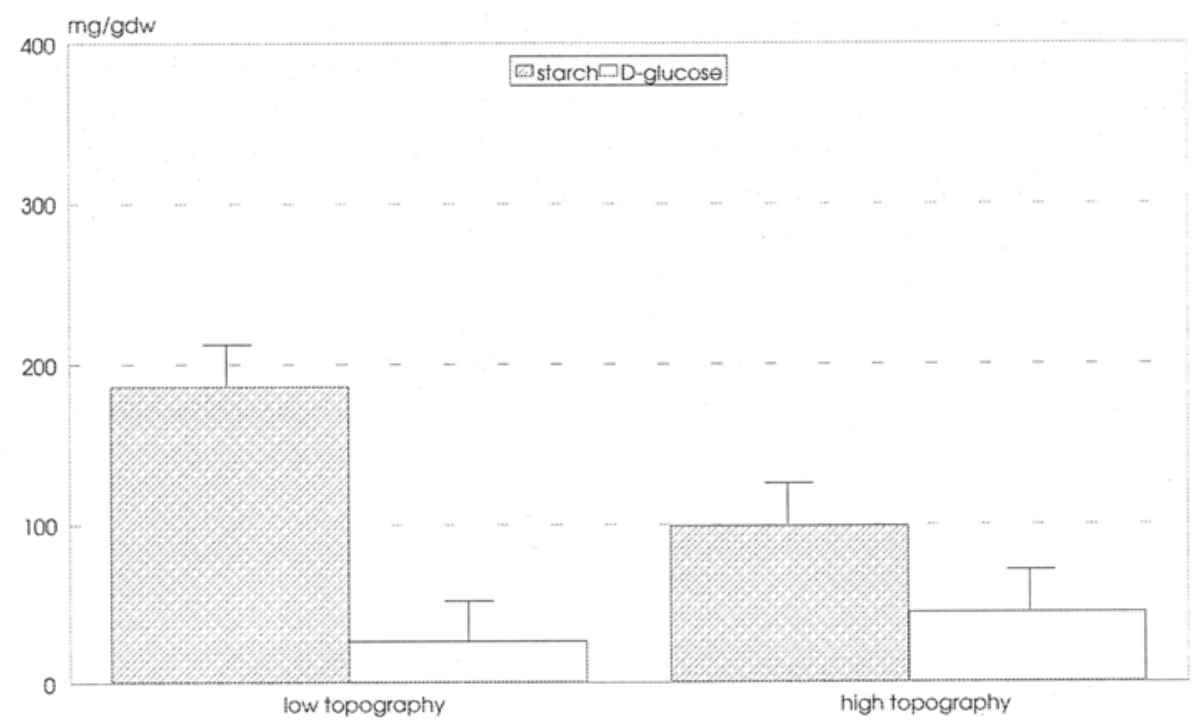

Figure 4. Mean starch and D-glucose concentration ( $\left.\mathrm{mg}_{\mathrm{gdw}} \mathrm{gd}^{-1}\right)$ of five saplings of Carapa guianensis Aubl. in areas of high and low topography in an Amazonian tidal várzea forest, before the onset of the wet season. Flooding is longer and more frequent for the lower areas. Bars indicate standard error.

Cattânio et al. (in preparation) show that the low topographic areas of Combu Island have higher density and lower species diversity than the higher areas, being characteristically populated by palm trees. This fact suggests a higher degree of adaptation to flooding by palm trees than by any other plant group in the forest. However, this was not reflected in the root food storage of the palm saplings prior to flooding. Setter et al.(1987) say that plants with shoot in air and roots deprived of oxygen, usually have higher concentrations of carbohydrate than totally aerobic plants. The increase in carbohydrate levels due to reduced use in growth, generally exceeds the depletion of carbohydrate that results from low photosynthesis, often due to high stomatal resistance and accelerated breakdown of carbohydrates in anaerobic conditions. Nevertheless, apart from presenting lower amounts of root carbohydrate than the other groups of plants (leguminous and others), the palms in the low waterlogged areas actually showed less carbohydrate stored than the high dry ones. This fact is particularly unexpected if one considers that at the time when root harvest was made, plants should be gathering reserves for the following wet season, when they become permanently flooded. This result could be explained by one or more of the following hypotheses: 
i) carbohydrate reserves could be stored in aerial roots or in the shoots and allocated to the underground roots when needed. Translocation of carbohydrates to roots is often reduced by flooding (Kozlowski \& Pallardy, 1984) and is a major limiting factor in determining the length of anaerobic life (Brändle \& Crawford 1987);

ii) the ventilation system of these plants could be such that they do not need to previously store food to survive long periods of flooding, being able to rely on currently produced carbohydrates throughout the year. Worbes (1986) however, studying plants of seasonal várzea and igapó, did not find air transport systems for the ninety tree species he investigated, although it is relevant to mention that this survey did not include palms.

iii) these species could be gathering carbohydrate during the wet season for consumption during the dry season, rather than the opposite. Keel \& Prance (1979) studying igapó flooded forests suggested that drought may represent more of an impairment to survival than flooding to the local vegetation. The same could possibly be true for the case of the tidal várzeas.

If any of the hypotheses above are true, reduced carbohydrate levels in the roots of the waterlogged palm saplings would not mean maladaptation.

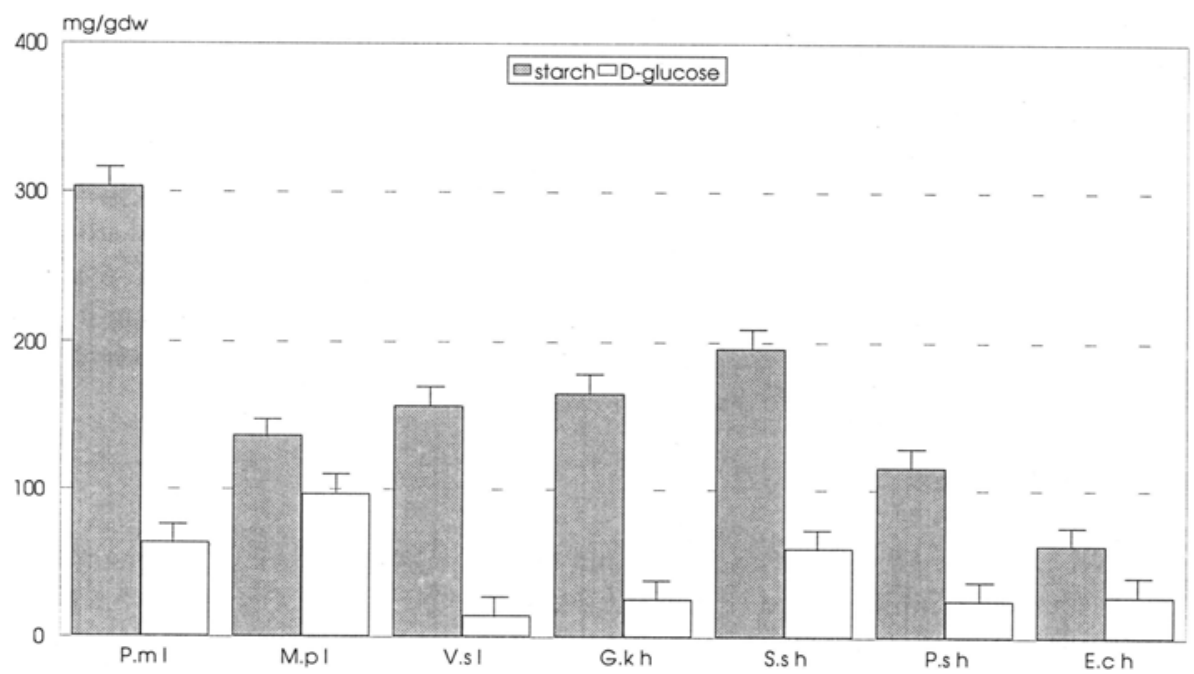

Figure 5. Mean starch and D-glucose concentration (mg.gdw $\left.{ }^{-1}\right)$ of saplings of seven dicotyledonous tree species belonging to six non-leguminous families, present in areas of high $(h)$ and/or low $(l)$ topography in an Amazonian tidal várzea forest, before the onset of the wet season: Pseudobombax munguba $(P . m)$ and Matisia paraensis (M.p), Bombacaceae; Virola surinamensis (V.s), Myristicaceae; Guarea kunthiana (G.k), Meliaceae; Sterculia speciosa (S.s), Sterculiaceae; Protium sp (P.s), Burseraceae; Eschweilera coriacea $(E . c)$, Lecythidaceae. Flooding is longer and more frequent for the lower areas. Bars indicate standard error. $\mathrm{n}=5$. 
The leguminous plants showed considerable intra and interspecific difference. Inga nobilis, although present in both high and low areas is possibly not as adapted to the lower areas as Inga edulis, as seen by the carbohydrate figures. Indeed, the latter appears predominantly in the low waterlogged areas. Pentaclethra macroloba seems to be well adapted to low topographies, where the individuals show considerably more reserves than in high areas. The results with the species of the genus Pithecellobium were rather surprising. Pithecellobium cauliflorum, a predominantly high area species, had $87 \%$ higher starch levels than Pithecellobium latifolium, its characteristically low area species. The hypotheses formulated for the palms above are also possibly applied for Pithecellobium latifolium. This species is characterised by producing pneumatophores which should enhance internal aeration.

Among the other dicotyledonous species, Carapa guianensis, commonly seen in both high and low areas, is probably the most curious case. Although expectedly showing a higher total carbohydrate in the low areas, this species showed a differentiation in the type of carbohydrate accumulated. The low area plants showed increased starch and reduced glucose compared with the high area roots. Starch reserves are important in avoiding shortage of food reserves for growth when favorable environmental conditions induce a greater food consumption than can be replaced by current production of photosynthates (Ericsson \& Persson 1980). Glucose and soluble sugars in general might play a role in preserving ultrastructure and survival of root tips (Setter et al. 1987).

The ability of some tidal várzea plants to store carbohydrates in their root systems during the growing season, therefore, appears to be one of the adaptations that accounts to their success in surviving long periods of flooding. Nevertheless, as seen in the cases of the highly flood-adapted palms and the leguminous species Pithecellobium latifolium, food storage is either unnecessary during the dry season, suggesting the existence of other adaptive mechanisms to flooding, or, conversely, food storage takes place during the wet season to allow the plants to survive the dry season. However, future work analysing carbohydrate reserves and depletion during a wet season shall be necessary in order to have a complete view of the role of carbohydrate storage in plant survival in tidal várzea forests.

\section{Acknowledgements}

We thank the Overseas Developmental Agency (British Council) for financing, Museu Paraense Emílio Goeldi for logistic support, Mr. Oscar Quaresma for field identification of the plants, the people of Combu Island for their patience and support, Mr. Harry Hodge for laboratorial support in St.Andrews, and two anonymous reviewers for their helpful comments and suggestions.

\section{References}

Boehringer \& Mannheim. 1987. UV-method for the determination of native starch in foodstuffs and other materials (kit's instruction leaflet). 
Brändle, R. \& Crawford, R.M.M. 1987. Rhizome anoxia tolerance and habitat specialization in wetland plants. In Crawford, R.M.M. (ed.) Plant Life in Aquatic and Amphibious Habitats. Oxford: Blackwell Scientific Publications. p. 397-410.

Crawford, R.M.M. 1992. Oxygen as an ecological limit to plant distribution. Advances in Ecological Research 23: 93-185.

Crawford, R.M.M.; Studer, C. \& Studer, K. 1989. Deprivation indifference as a survival strategy in competition: advantages and disadvantages of anoxia tolerance in wetland vegetation. Flora 182: 189-201.

Ericsson, A. \& Persson, H., 1980. Seasonal changes in starch reserves and growth of fine roots of 20-yearold Scots pines. Ecol.Bull. 32: 239-250.

Figueiredo-Ribeiro, R.C.L.; Dietrich, S.M.C.; Chu, E.P.; Machado de Carvalho, M.A.; Vieira, C.C.J. \& Graziano,T.T. 1986. Reserve carbohydrates in underground organs of native Brazilian plants. Revta. bras. Bot. 9: 159-166.

Junk, W.J. 1989. Flood tolerance and tree distribution in Central Amazonian floodplains. In HolmNielson, L.B. et al. (eds.). Tropical Forests - Botanical Dynamics, Speciation and Diversity: Academic Press. p.47-64.

Keel, S.H.K. \& Prance, G.T. 1979. Studies of the vegetation of a white-sand blackwater igapó (Rio Negro, Brazil). Acta Amazonica 9(4):645-655.

Kozlowski, T.T. \& Keller,T. 1966. Food relations of woody plants. Bot. Rev. 32(4):293-382.

Kozlowski, T.T \& Pallardy, S.G. 1984. Effect of flooding on water, carbohydrate and mineral relations. In Kozlowski, T.T.(ed.). Flooding and Plant Growth. Academic Press. p.165-193.

Prance, G.T. 1979. Notes on the vegetation of the Amazon III. The terminology of Amazonian forest types subject to inundation. Brittonia 31(1):26-38.

Scarano, F.R. \& Crawford, R.M.M. 1992. Ontogeny and the concept of anoxia-tolerance: the case of the Amazonian leguminous tree Parkia pendula. Journal of Tropical Ecology 8: 349-352.

Setter, T.L.; Waters, J.; Atwell, B.J.; Kapanchanakul, T. \& Greenway, H. 1987. Carbohydrate status of terrestrial plants during flooding. In Crawford, R.M.M. (ed.). Plant Life in Aquatic and Amphibious Habitats. Oxford: Blackwell Scientific Publications. p. 411-433.

Steinmann, F. \& Brändle, R. 1984. Carbohydrate and protein metabolism in the rhizomes of the bullrush (Schoenoplectus lacustris L. Palla) in relation to natural development of the whole plant. Aquatic Botany 19: 53-63.

Worbes, M. 1985. Structural and other adaptations to long-term flooding by trees in Central Amazonia. Amazoniana 9(3): 459-484.

Worbes, M. 1986. Lebensbedingungen und Holzwachstum in zentralamazonischen Uberschwemmungswaldern. Scripta geobotanica 17. 